\title{
Standardisation of Gamma Dose in Papaya cv. Ranchi Local and Arka Surya
}

\author{
Prativa Sahu ${ }^{\text {** }}$, D. K. Dash ${ }^{2}$, J. Lenka ${ }^{3}$, S. N. Dash², S. K. Tripathy ${ }^{2}$, \\ A. Mishra ${ }^{2}$ and A. Sahu ${ }^{4}$ \\ ${ }^{1}$ Department of Fruit Science, ICAR-Indian Institute of Water Management, \\ C.S.Pur, Bhubaneswar, Odisha-751023, India \\ ${ }^{2}$ College of Agriculture, Odisha University of Agriculture \& Technology, \\ Bhubaneswar, Odisha-751003, India \\ ${ }^{3}$ ICAR-Central Institute for Subtropical Horticulture, Rehmankhera, P.O. Kakori, \\ Lucknow, Uttar Pradesh 226101, India \\ ${ }^{4}$ ICAR-Central Institute for Women in Agriculture, Bhubaneswar, Odisha - 751003, India \\ *Corresponding author
}

\begin{tabular}{|l|}
\hline Ke y w o r d s \\
Papaya, Gamma \\
rays, LD50, \\
germination, GR50, \\
GR30 \\
\hline Article Info \\
\hline $\begin{array}{l}\text { Accepted: } \\
\text { 04 September } 2019 \\
\text { Available Online: } \\
\text { 10 October } 2019\end{array}$ \\
\hline
\end{tabular}

A B S T R A C T
Gamma radiation is the most commonly used mutagen in plants as it causes a high frequency of induced mutations. It can be used to overcome the difficulties in papaya breeding to get true to type plantlets especially in dioecious varieties. An optimum dose is highly desired to produce the high frequency of mutations with minimum killing of treated individuals. Therefore, the present investigation was undertaken to determine the $\mathrm{LD}_{50}$ of gamma rays and effect of different dosages of gamma rays on morphological, physiochemical, biochemical parameters of papaya. In the preliminary dosimetry study, seeds from two papaya varieties, Ranchi Local and Arka Surya were irradiated in a gamma chamber at Bhabha Atomic Research Centre (BARC), Mumbai with 7 different radiation doses ranging from $10 \mathrm{~Gy}$ to $70 \mathrm{~Gy}$ at every interval of $10 \mathrm{~Gy}$. Prior to irradiation in one experiment, seeds were soaked overnight in water and surface-dried and in another experiment, seeds were immersed in water while irradiation. Radio sensitivity test of germinated seeds showed that the $\mathrm{LD}_{50}$ value was 28.35 and 33.13 Gy for pre-soaked seeds \& 24.05 and 23.78 Gy for seeds immersed in water for Ranchi Local \& Arka Surya variety respectively. The $\mathrm{GR}_{50}$ was thus calculated to be 31.64 and $37.50 \mathrm{~Gy}$ for presoaked seeds \& 28.28 and 30.11 Gy for seeds immersed in water for Ranchi Local \& Arka Surya variety respectively. From the analysis of $\mathrm{GR}_{50}$ for both the irradiated conditions, it was found that $30 \mathrm{~Gy}$ (for pre-soaked seeds) and $20 \mathrm{~Gy}$ (for seeds immersed in water) was the most effective dose with maximum possibility of desirable mutation. 


\section{Introduction}

The papaya (Carica papaya L.), belongs to the family Caricaceae, which consists of 55 species (Dallwitz, 1980). The common papaya is believed to have originated from the lowlands of Mesoamerica, in a region from southern Mexico to (possibly) as far south as Nicaragua (Purseglov, 1974). It was introduced to India in the early part of 16th century from Phillippines through Malaysia (Schroeder, 1958). Owing to unique characteristics of papaya, its cultivation has become very popular among the fruit growers. Being short duration, early maturing, quick growing and dwarf in nature, it is grown very successfully as intercrop in the orchards of major fruit crops (Chattopadhyay, 2012). It is a digestive aid and is a stomachic, carminative, diuretic and expectorant. Among the fruits, it ranks 4th position in production $(61,08,000 \mathrm{MT}), 1$ st position in productivity (44.9 MT/Ha) from 132000 ha (MoAFW, 2017).

Plant breeding methods have contributed immensely to the development of genetically improved crop varieties. These methods continue to enrich the crop germplasm base by evolving genetically superior varieties for cultivation. Existing germplasm resources may not be adequate to meet the food needs of an ever increasing human population, estimated to swell to nine billion by 2050 (Green et al., 2005). Further increase in agricultural productivity, equitably and in an environmentally sustainable manner, in the face of limiting resources, is a challenging task. Genetic improvement to tackle the production bottlenecks through traditional breeding procedures has not been very successful (Beyene et al., 2013). Due to the complex sex forms improving papaya with conventional methods, alternative approaches such as mutation induction have been pursued. The work on the induction of genetic alterations through X-rays by Lewis John Stadler in the late 1920s and early 1930's laid the foundation of another type of plant breeding known as mutation breeding (Shu et al., 2012). Mutagenesis is the process whereby sudden heritable changes occur in the genetic information of an organism not caused by genetic segregation or genetic recombination, but induced by chemical, physical or biological agents (Roychowdhury and Tah, 2013).

Among the physical mutagens, gamma ray stands first in its effectiveness in the induction of mutation in crop plants (Jan et al., 2011; Verma et al., 2012).Gamma rays, X-rays, visible light and UV are all electromagnetic (EM) radiation. Gamma rays are the electromagnetic radiation with highest form of energy having energy level ranging from 10 $\mathrm{keV}$ to several hundred $\mathrm{keV}$, with higher penetration capacity (Kovacs and Keresztes, 2002). Low dose gamma irradiation on plants is helpful in enhancing growth, chlorophyll pigment along with yield in okra [Hegazi A. Z. and Hamideldin N. J., 2010]. Gamma rays obtained from radioactive isotope of cobalt $\left({ }^{60} \mathrm{Co}\right)$ are widely used. The isotope has a half-life of 5.3 years and emits radiations of energies $1.33 \mathrm{MeV}$ and 1.17 $\mathrm{MeV}$. Since the dose rate for a given irradiator is fixed, the dose is varied by determining duration for which the sample should be exposed to the source. The material does not have added or induced radioactivity and hence can be handled after treatment without any precautions.

To obtain a mutant, the dose of the mutagen should be sufficiently high to increase the probability of inducing a mutation; however, it should not be so high as to cause damage to the cells/ tissues resulting in lethality. Radiation dose is expressed in rads (radiationabsorbed dose) which is equivalent to 
absorption of 100 ergs/g. The unit kilorad (kR which is 1,000 rads) which was in use earlier is replaced by gray (Gy) which is currently used. The two can be interconvert as $1 \mathrm{kR}$ is equivalent to $10 \mathrm{~Gy}$. A concept of $\mathrm{LD}_{50}$ (lethal dose $50 \%$ ) is used to refer the optimum dose to be used in the experiment. By definition $\mathrm{LD}_{50}$ is the dose which causes $50 \%$ lethality in the organism used for irradiation in defined time. It varies with the plant species, the type and status of the material and the stage at which lethality is measured. Generally, irradiated populations are generated by using an $\mathrm{LD}_{50}$ dose treatment and with a dose lower than $\mathrm{LD}_{50}$. Since induction of mutation is a chance event, and recovery of a mutation is dependent upon chance of the survival of that individual plant, this strategy improves the probability of obtaining a desirable mutant. In a case where $\mathrm{LD}_{50}$ dose is already reported, it can be used as a guideline; otherwise, it can be determined by exposing different subsamples of the target plant material (seeds) to a range of doses (low to high) and monitoring survival of the plants in field (up to flowering or maturity). In plants which are sensitive to radiation, doses lower than $\mathrm{LD}_{50}$ are also used to reduce the mutation load (Shu et al., 2012). Therefore, it is preferred to work out radio sensitivity test between $\mathrm{LD}_{25}$ or $\mathrm{LD}_{30}$ and $\mathrm{LD}_{50}$ to obtain mutation for desired and optimum traits (Choudhury 1983; Maluszynski et al., 2003). This necessitates the present investigation entitled "Standardization of gamma dose for papaya cv. Ranchi Local and Arka Surya.

\section{Materials and Methods}

An investigation was carried out at Horticulture Research Station, Odisha University of Agriculture \& Technology, Bhubaneswar, Odisha, India during 2016-2019 to study the proper dose for induction of mutation in papaya. Geographically, Bhubaneswar lies in the tropical zone and experience warm humid climate. It is characterized by three well defined seasons that dominates the city are summer, rainy and winter. The minimum and maximum temperature of the location varies between $15^{\circ} \mathrm{C}$ to $40^{\circ} \mathrm{C}$. The average rainfall is about $1540 \mathrm{~mm}$. It lies between $20^{\circ} 15^{\prime}$ North latitude and $85^{\circ} 52^{\prime}$ East longitude and at an average altitude of $45 \mathrm{~m}$ above sea level. Bhubaneswar is located on the coastal plains of Odisha, south-west of the River Mahanadi. It comes under the east and south eastern coastal plain agro-climatic zone of Odisha and the east coastal plains and hills zone of the humid tropics of India.

The experiment was laid out in a Factorial Randomized Block Design with three levels viz two varieties, two soaking conditions and seven different gamma doses. In the preliminary dosimetry study, seeds from two papaya varieties, Ranchi Local (dioecious) and Arka Surya (gynodioecious) were irradiated in a gamma chamber at Bhabha Atomic Research Centre (BARC), Mumbai. To find out the lethal dose for $50 \%$ of the population the seeds were irradiated at different dose starting from $10 \mathrm{~Gy}$ to $70 \mathrm{~Gy}$ at every interval of $10 \mathrm{~Gy}$ i.e.10Gy, 20 Gy,30 Gy,40 Gy,50 Gy,60 Gy and $70 \mathrm{~Gy}$. The source of radiation in the chamber is $\mathrm{Co}^{60}$, which emits 2 gamma radiation of energy 1.33 and $1.17 \mathrm{MeV}$ per disintegration. The dose rate was of the order of $17 \mathrm{~Gy} / \mathrm{min}$. Prior to irradiation in one experiment, seeds were soaked overnight in water and surface-dried and in another experiment, seeds were immersed in water while irradiation for a better diffusion of the gamma rays. After irradiation, the seeds were removed from the water and grown in greenhouses belonging to Department of Fruit Science \& Horticulture Technology, OUAT, Bhubaneswar, Odisha under controlled conditions. For each treatment 250 numbers of seeds were used. The observation on seed germination (\%), shoot 
length $(\mathrm{cm})$, root length $(\mathrm{cm})$, seedling height (cm) was recorded.

\section{Results and Discussion}

\section{Germination percentage}

A glance at the data presented in Table 1 clearly revealed significant variation among the treatments for germination percentage in papaya cv. Ranchi Local \& Arka Surya.

Variety Arka Surya had recorded higher (36.50\%) germination than var. Ranchi Local $(31.75 \%)$, irrespective of seed soaking conditions and gamma doses. The result also brought to light that higher rate of germination $(43.93 \%)$ by pre-soaked treatment as against seeds immersed in water $(24.33 \%)$, irrespective of variety and gamma doses.

The result of gamma irradiation doses to papaya seeds unveiled that highest (65.83\%) germination was recorded by $10 \mathrm{~Gy}$ as compared to other doses, irrespective of variety and seed soaking conditions.

However, 50 Gy had marked lowest germination $(5.38 \%)$. Interaction of variety with soaking treatment showed that Arka Surya var. with pre-soaked condition had highest germination percentage (48.2\%). However, Arka Surya at $10 \mathrm{~Gy}$ had maximum germination percentage (68.7\%) under the interaction treatment of variety with doses (Table 2).

Interaction between seed soaking condition and doses found to be significant with highest germination percentage $(76.3 \%)$ at 10 Gy in pre-soaked conditions. Interaction of variety, seed soaking condition and gamma doses disclosed that Arka Surya var. in pre-soaked condition at $10 \mathrm{~Gy}$ had highest germination percentage $(78.6 \%)$. With the increasing gamma dose there was a significant decrease in germination percentage irrespective of variety and seed soaking conditions.

\section{Soot length}

With respect to the parameter shoot length, variety Arka Surya had inscribed maximum $(7.84 \mathrm{~cm})$ than var. Ranchi Local $(5.58 \mathrm{~cm})$, irrespective of seed soaking conditions and gamma doses. The result also notified the highest shoot length $(7.51 \mathrm{~cm})$ by pre-soaked treatment as against seeds immersed in water $(5.91 \mathrm{~cm})$, irrespective of variety and gamma doses. Interaction of variety with soaking treatment presented in Table 2 clearly showed that Arka Surya var. with pre-soaked condition had highest germination percentage $(8.62 \mathrm{~cm})$. However, Arka Surya at $10 \mathrm{~Gy}$ had maximum shoot length $(12.0 \mathrm{~cm})$ under the interaction treatment of variety with doses. Interaction of variety, seed soaking condition and gamma doses revealed that Arka Surya var. in pre-soaked (PS) condition at $10 \mathrm{~Gy}$ had highest shoot length $(12.4 \mathrm{~cm})$. Gamma ray imposed a significant impact on the shoot length. It was observed that there was a decreasing trend with increase in irradiation doses irrespective of varieties and seed soaking conditions. However, the effect was more pronounced when seeds immersed in water during irradiation than pre-soaked seeds prior to irradiation.

\section{Root length}

Regarding doses of gamma irradiation to papaya seeds, the result revealed that significantly maximum average root length $(15.52 \mathrm{~cm})$ was recorded by 20 Gy as compared to other doses, irrespective of variety and seed soaking conditions. However, 50 Gy had significantly lowest root length $(4.75 \mathrm{~cm})$. Interaction of variety with soaking treatment presented in Table 3 clearly showed that Ranchi Local var. with pre-soaked condition had highest root length $(13.88 \mathrm{~cm})$. 
However, Ranchi Local at 30 Gy had maximum root length $(18.02 \mathrm{~cm})$ under the interaction treatment of variety with doses.

\section{Seedling height}

Variety Ranchi Local had significantly highest $(18.46 \mathrm{~cm})$ than var. Ranchi Local $(17.70 \mathrm{~cm})$, irrespective of seed soaking conditions and gamma doses. The result also affirmed that higher seedling height $(19.21 \mathrm{~cm})$ by presoaked treatment as against seeds immersed in water $(16.94 \mathrm{~cm})$ irrespective of variety and gamma doses. The results corresponding to the gamma irradiation of papaya seeds proclaim that the highest seedling height $(24.39 \mathrm{~cm})$ was observed at $10 \mathrm{~Gy}$ as compared to other doses, regardless of variety and seed soaking conditions. However, 50 Gy had shown lowest seedling height $(7.35 \mathrm{~cm})$.

\section{Standardization of $\mathbf{L D}_{50}, \mathbf{G R}_{\mathbf{5 0}}$ \& $\mathbf{G R}_{\mathbf{3 0}}$}

An empirical formula was derived from the radio sensitivity test of germinated seeds presented in Fig. 1, which was used to calculate lethal dose for $50 \%$ population $\left(\mathrm{LD}_{50}\right)$. The $\mathrm{LD}_{50}$ value was 28.35 and 33.13 Gy for pre-soaked seeds \& 24.05 and 23.78 Gy for seeds immersed in water for Ranchi Local \& Arka Surya variety respectively. Similarly the shoot length data of germinated papaya seeds was used to derive an empirical formula for determination of $\mathrm{GR}_{50} \& \mathrm{GR}_{30}$ which is presented in Fig. 2. The $\mathrm{GR}_{50}$ was thus calculated to be 31.64 and $37.50 \mathrm{~Gy}$ for pre-soaked seeds \& 28.28 and $30.11 \mathrm{~Gy}$ for seeds immersed in water for Ranchi Local \& Arka Surya variety respectively. GR $_{30}$ was also calculated from the same equation and found out to be that 44.30 and $52.50 \mathrm{~Gy}$ for pre-soaked seeds \& 39.59 and 42.15 Gy for seeds immersed in water for Ranchi Local \& Arka Surya respectively. From the analysis of $\mathrm{GR}_{50}$ for both the irradiated conditions, it was found that $30 \mathrm{~Gy}$ (for pre-soaked seeds) and $20 \mathrm{~Gy}$ (for seeds immersed in water) was the most effective dose with maximum possibility of desirable mutation.

Results regarding the effect of radiation exposure on germination are variable, especially when pre-irradiation treatments are involved. In various experiments, parameters such as germination rate and per cent are reported to increase, decrease, or remain unchanged after irradiation. Higher exposures were usually inhibitory (Bora, 1961; Radhadevi and Nayar, 1996; Kumari and Singh, 1996).

The inability of seeds to germinate at higher doses of gamma rays has been attributed to several reasons: $(i)$ numerous histological and cytological changes; (ii) disruption and disorganisation of the tunica or seed layer that is directly proportional to the intensity of exposure to g-rays; (iii) impaired mitosis or virtual elimination of cell division in the meristematic zones during germination (Lokesha et al., 1992). The inhibition of seed germination and seedling growth exerted by irradiation has often been ascribed to the formation of free radicals in irradiated seeds (Kumagai et al., 2000; Kovács and Keresztes 2002). The stimulation for germination at lower doses can be attributed to the concept of hormesis, the stimulation of different biological processes (e.g., faster germination, increased growth of roots and leaves), that occurs when seeds are subjected to preirradiation with low doses of a radiation source (Luckey 1980; Bayonove, et al., 1984; Zimmermann et al., 1996; Sparrow 1966; Thapa 1999). The stimulatory effects of g-rays on germination may be attributed to the activation of RNA synthesis (Kuzin et al., 1975) on castor bean (Ricinus communis L.) or protein synthesis (Kuzin et al., 1976), which occurred during the early stage of germination after seeds irradiated with $4 \mathrm{krad}$ (40 Gy). This could be due to the enhanced rate of respiration or auxin metabolism in seedlings (Fig. 1-9 and Table 1-5). 
Table.1 Effect of irradiation and seed soaking on germination, shoot length, root length and seedling height in papaya cv. Ranchi Local \& Arka Surya

\begin{tabular}{|c|c|c|c|c|c|c|}
\hline & & & Germination (\%) & $\begin{array}{l}\text { Shoot Length } \\
\text { (cm) }\end{array}$ & $\begin{array}{l}\text { Root length } \\
\text { (cm) }\end{array}$ & $\begin{array}{c}\text { Seedling } \\
\text { Height }(\mathbf{c m})\end{array}$ \\
\hline \multicolumn{3}{|c|}{ Ranchi Local $\left(\mathrm{A}_{1}\right)$} & 31.75 & 5.58 & 12.88 & 18.46 \\
\hline \multicolumn{3}{|c|}{ Arka Surya $\left(\mathbf{A}_{2}\right)$} & 36.50 & 7.84 & 9.86 & 17.70 \\
\hline \multicolumn{3}{|c|}{$\mathbf{S E d}_{( \pm)}$} & 0.59 & 0.08 & 0.13 & 0.18 \\
\hline \multicolumn{3}{|c|}{$\mathrm{CD}_{0.05}$} & 1.20 & 0.15 & 0.26 & 0.36 \\
\hline \multicolumn{3}{|c|}{ Pre Soaked $\left(\mathbf{B}_{1}\right)$} & 43.93 & 7.51 & 11.70 & 19.21 \\
\hline \multicolumn{3}{|c|}{ Seeds in water $\left(B_{2}\right)$} & 24.33 & 5.91 & 11.03 & 16.94 \\
\hline \multicolumn{3}{|c|}{ SEd $_{( \pm)}$} & 0.59 & 0.08 & 0.13 & 0.18 \\
\hline \multicolumn{3}{|c|}{$\mathrm{CD}_{0.05}$} & 1.20 & 0.15 & 0.26 & 0.36 \\
\hline \multicolumn{3}{|c|}{$10 \mathrm{~Gy}\left(\mathrm{C}_{1}\right)$} & 65.83 & 10.72 & 13.68 & 24.39 \\
\hline \multicolumn{3}{|c|}{$20 \mathrm{~Gy}\left(\mathrm{C}_{2}\right)$} & 49.06 & 8.63 & 15.52 & 24.15 \\
\hline \multicolumn{3}{|c|}{$30 \mathrm{~Gy}\left(\mathrm{C}_{3}\right)$} & 31.97 & 6.75 & 14.42 & 21.17 \\
\hline \multicolumn{3}{|c|}{$40 \mathrm{~Gy}\left(\mathrm{C}_{4}\right)$} & 18.40 & 4.85 & 8.46 & 13.31 \\
\hline \multicolumn{3}{|c|}{$50 \mathrm{~Gy}\left(\mathrm{C}_{5}\right)$} & 5.38 & 2.60 & 4.75 & 7.35 \\
\hline \multicolumn{3}{|c|}{ SEd $_{( \pm)}$} & 0.94 & 0.12 & 0.20 & 0.28 \\
\hline \multicolumn{3}{|c|}{$\mathrm{CD}_{0.05}$} & 1.90 & 0.24 & 0.41 & 0.57 \\
\hline \multirow[t]{2}{*}{ AXB } & \multicolumn{2}{|c|}{$\mathrm{SEd}_{( \pm)}$} & 0.84 & 0.11 & 0.18 & 0.25 \\
\hline & \multicolumn{2}{|c|}{$\mathrm{CD}_{0.05}$} & 1.70 & NS & 0.37 & 0.51 \\
\hline \multirow[t]{2}{*}{ AXC } & \multicolumn{2}{|c|}{$\mathrm{SEd}_{( \pm)}$} & 1.33 & 0.17 & 0.29 & 0.40 \\
\hline & \multicolumn{2}{|c|}{$\mathrm{CD}_{0.05}$} & 2.69 & 0.34 & 0.58 & 0.80 \\
\hline \multirow[t]{2}{*}{ BXC } & \multicolumn{2}{|c|}{$\mathrm{SEd}_{( \pm)}$} & 1.33 & 0.17 & 0.29 & 0.40 \\
\hline & \multicolumn{2}{|c|}{$\mathrm{CD}_{0.05}$} & 2.69 & NS & 0.58 & 0.80 \\
\hline \multirow[t]{2}{*}{ AXBXC } & \multicolumn{2}{|c|}{$\mathrm{SEd}_{( \pm)}$} & 1.88 & 0.24 & 0.40 & 0.56 \\
\hline & \multicolumn{2}{|c|}{$\mathrm{CD}_{0.05}$} & 3.80 & 0.48 & 0.82 & 1.14 \\
\hline \multirow{4}{*}{$\begin{array}{c}\text { Control } \\
\text { Vs } \\
\text { Rest (Mean) }\end{array}$} & \multirow[t]{2}{*}{$\mathrm{A}_{1}$} & Control & 72.13 & 10.50 & 7.60 & 20.20 \\
\hline & & Rest & 31.75 & 5.58 & 12.88 & 18.46 \\
\hline & \multirow[t]{2}{*}{$\mathrm{A}_{2}$} & Control & 65.48 & 12.60 & 6.24 & 16.74 \\
\hline & & Rest & 36.50 & 7.84 & 9.86 & 17.70 \\
\hline Control & $\mathrm{A}_{1}$ & $\mathrm{SEd}_{( \pm)}$ & 1.41 & 0.16 & 0.30 & 0.38 \\
\hline $\begin{array}{c}\text { Vs } \\
\text { Rest }\end{array}$ & & $\mathrm{CD}_{0.05}$ & 2.94 & 0.34 & 0.63 & 0.81 \\
\hline & $\mathrm{A}_{2}$ & $\mathrm{SEd}_{( \pm)}$ & 1.52 & 0.21 & 0.33 & 0.43 \\
\hline & & $\mathrm{CD}_{0.05}$ & 3.17 & 0.45 & 0.70 & 0.91 \\
\hline
\end{tabular}


Table.2 Interaction effect of irradiation and seed soaking on germination \& shoot length in papaya cv. Ranchi Local \& Arka Surya

\begin{tabular}{|c|c|c|c|c|c|c|c|c|c|c|c|c|c|c|}
\hline \multirow{3}{*}{$\begin{array}{c}\text { Dose (Gy) } \\
(C)\end{array}$} & \multicolumn{7}{|c|}{ Germination (\%) } & \multicolumn{7}{|c|}{ Shoot length $(\mathrm{cm})$} \\
\hline & \multicolumn{2}{|c|}{$\mathrm{A}_{1}$} & \multirow{2}{*}{$\begin{array}{l}\text { Mean } \\
\mathrm{A}_{1} \mathrm{~B}\end{array}$} & \multicolumn{2}{|c|}{$\mathrm{A}_{2}$} & \multirow{2}{*}{$\begin{array}{c}\text { Mean } \\
\mathrm{A}_{2} \mathrm{~B}\end{array}$} & \multirow{2}{*}{$\begin{array}{c}\text { Mean } \\
\text { AB }\end{array}$} & \multicolumn{2}{|c|}{$\mathrm{A}_{1}$} & \multirow{2}{*}{$\begin{array}{c}\text { Mean } \\
\mathrm{A}_{1} \mathrm{~B}\end{array}$} & \multicolumn{2}{|c|}{$\mathrm{A}_{2}$} & \multirow{2}{*}{$\begin{array}{c}\text { Mean } \\
\mathrm{A}_{2} \mathrm{~B}\end{array}$} & \multirow{2}{*}{$\begin{array}{c}\text { Mean } \\
\mathrm{AB}\end{array}$} \\
\hline & $\mathrm{B}_{1}$ & $\mathrm{~B}_{2}$ & & $\mathrm{~B}_{1}$ & $\mathrm{~B}_{2}$ & & & $\mathrm{~B}_{1}$ & $\mathrm{~B}_{2}$ & & $\mathrm{~B}_{1}$ & $\mathrm{~B}_{2}$ & & \\
\hline Control & \multicolumn{2}{|c|}{72.13} & & \multicolumn{2}{|c|}{65.48} & & & \multicolumn{2}{|c|}{10.50} & & \multicolumn{2}{|c|}{12.60} & & \\
\hline 10 & 74.11 & 51.82 & 62.97 & 78.56 & 58.84 & 68.70 & 65.26 & 10.42 & 8.43 & 9.43 & 12.40 & 11.61 & 12.01 & 10.72 \\
\hline 20 & 58.26 & 32.22 & 45.24 & 69.16 & 36.62 & 52.89 & 48.30 & 8.16 & 6.86 & 7.51 & 10.44 & 9.05 & 9.75 & 8.63 \\
\hline 30 & 35.64 & 22.51 & 29.07 & 51.48 & 18.24 & 34.86 & 31.39 & 6.40 & 4.38 & 5.39 & 8.72 & 7.51 & 8.11 & 6.75 \\
\hline 40 & 21.18 & 11.56 & 16.37 & 31.52 & 9.32 & 20.42 & 17.99 & 4.20 & 2.65 & 3.43 & 7.14 & 5.42 & 6.28 & 4.85 \\
\hline 50 & 8.89 & 1.35 & 5.12 & 10.45 & 0.82 & 5.64 & 5.33 & 2.80 & 1.51 & 2.15 & 4.40 & 1.69 & 3.05 & 2.60 \\
\hline Mean & 39.62 & 23.89 & & 48.23 & 24.77 & & & 6.40 & 4.76 & & 8.62 & 7.06 & & \\
\hline
\end{tabular}

Table.3 B X C mean data for germination \& shoot length in papaya cv. Ranchi Local \& Arka Surya

\begin{tabular}{|c|c|c|c|c|c|c|c|c|c|c|c|c|c|}
\hline \multicolumn{7}{|c|}{ \% Germination (B X C Mean Table) } & \multicolumn{7}{|c|}{ Shoot Length (B X C Mean Table) } \\
\hline & $10 \mathrm{~Gy}$ & $20 \mathrm{~Gy}$ & $30 \mathrm{~Gy}$ & 40 Gy & $50 \mathrm{~Gy}$ & $\begin{array}{c}\text { Mean } \\
\text { B }\end{array}$ & & $10 \mathrm{~Gy}$ & $20 \mathrm{~Gy}$ & $30 \mathrm{~Gy}$ & 40 Gy & 50 Gy & $\begin{array}{c}\text { Mean } \\
\text { B }\end{array}$ \\
\hline $\begin{array}{c}\text { Pre- } \\
\text { soaked }\end{array}$ & 76.34 & 63.71 & 43.56 & 26.35 & 9.67 & 43.93 & $\begin{array}{c}\text { Pre- } \\
\text { soaked }\end{array}$ & 11.41 & 9.30 & 7.56 & 5.67 & 3.60 & 7.51 \\
\hline SIW & 55.33 & 34.42 & 20.37 & 10.44 & 1.09 & 24.33 & SIW & 10.02 & 7.96 & 5.94 & 4.04 & 1.60 & 5.91 \\
\hline $\begin{array}{c}\text { Mean } \\
\text { C }\end{array}$ & 65.83 & 49.06 & 31.97 & 18.40 & 5.38 & & $\begin{array}{c}\text { Mean } \\
\text { C }\end{array}$ & 10.72 & 8.63 & 6.75 & 4.85 & 2.60 & \\
\hline
\end{tabular}


Table.4 Interaction effect of irradiation and seed soaking on root length \& seedling height in papaya cv. Ranchi Local \& Arka Surya

\begin{tabular}{|c|c|c|c|c|c|c|c|c|c|c|c|c|c|c|}
\hline \multirow{3}{*}{$\begin{array}{c}\text { Dose (Gy) } \\
\text { (C) }\end{array}$} & \multicolumn{7}{|c|}{ Root Length (cm) } & \multicolumn{7}{|c|}{ Seedling Height (cm) } \\
\hline & \multicolumn{2}{|c|}{$\mathrm{A}_{1}$} & \multirow{2}{*}{$\begin{array}{c}\text { Mean } \\
\mathrm{A}_{1} \mathrm{~B}\end{array}$} & \multicolumn{2}{|c|}{$\mathrm{A}_{2}$} & \multirow{2}{*}{$\begin{array}{c}\text { Mean } \\
\mathrm{A}_{2} \mathrm{~B}\end{array}$} & \multirow{2}{*}{$\begin{array}{c}\text { Mean } \\
\text { AB }\end{array}$} & \multicolumn{2}{|c|}{$\mathrm{A}_{1}$} & \multirow{2}{*}{$\begin{array}{c}\text { Mean } \\
\mathrm{A}_{1} \mathrm{~B}\end{array}$} & \multicolumn{2}{|c|}{$\mathrm{A}_{2}$} & \multirow{2}{*}{$\begin{array}{c}\text { Mean } \\
\mathrm{A}_{2} \mathrm{~B}\end{array}$} & \multirow{2}{*}{$\begin{array}{c}\text { Mean } \\
\text { AB }\end{array}$} \\
\hline & $\mathrm{B}_{1}$ & $\mathrm{~B}_{2}$ & & $\mathrm{~B}_{1}$ & $\mathrm{~B}_{2}$ & & & $\mathrm{~B}_{1}$ & $\mathrm{~B}_{2}$ & & $\mathrm{~B}_{1}$ & $\mathrm{~B}_{2}$ & & \\
\hline Control & \multicolumn{2}{|c|}{7.61} & & \multicolumn{2}{|c|}{6.24} & & & \multicolumn{2}{|c|}{20.21} & & \multicolumn{2}{|c|}{16.74} & & \\
\hline 10 & 12.53 & 14.20 & 13.37 & 12.56 & 15.42 & 13.99 & 13.68 & 22.95 & 22.63 & 22.79 & 24.96 & 27.03 & 26.00 & 24.39 \\
\hline 20 & 15.82 & 18.05 & 16.94 & 16.83 & 11.38 & 14.10 & 15.52 & 23.98 & 24.91 & 24.45 & 27.27 & 20.43 & 23.85 & 24.15 \\
\hline 30 & 14.78 & 21.26 & 18.02 & 13.47 & 8.17 & 10.82 & 14.42 & 21.18 & 25.64 & 23.41 & 22.19 & 15.68 & 18.94 & 21.17 \\
\hline 40 & 8.98 & 11.53 & 10.26 & 8.61 & 4.72 & 6.67 & 8.46 & 13.18 & 14.18 & 13.68 & 15.75 & 10.14 & 12.95 & 13.31 \\
\hline 50 & 7.20 & 4.40 & 5.80 & 6.22 & 1.18 & 3.70 & 4.75 & 10.00 & 5.91 & 7.96 & 10.63 & 2.87 & 6.75 & 7.35 \\
\hline Mean & 11.86 & 13.89 & & 11.54 & 8.17 & & & 18.26 & 18.65 & & 20.16 & 15.23 & & \\
\hline
\end{tabular}

Table.5 B X C mean data for root length \& seedling height in papaya cv. Ranchi Local \& Arka Surya

\begin{tabular}{|c|c|c|c|c|c|c|c|c|c|c|c|c|c|}
\hline \multicolumn{7}{|c|}{ Root length (B X C Mean Table) } & \multicolumn{7}{|c|}{ Seedling Height (B X C Mean Table) } \\
\hline & $10 \mathrm{~Gy}$ & $20 \mathrm{~Gy}$ & 30 Gy & $40 \mathrm{~Gy}$ & 50 Gy & $\begin{array}{c}\text { Mean } \\
\text { B }\end{array}$ & & $10 \mathrm{~Gy}$ & $20 \mathrm{~Gy}$ & 30 Gy & $40 \mathrm{~Gy}$ & $50 \mathrm{~Gy}$ & $\begin{array}{c}\text { Mean } \\
\text { B }\end{array}$ \\
\hline $\begin{array}{c}\text { Pre- } \\
\text { soaked }\end{array}$ & 12.55 & 16.33 & 14.13 & 8.80 & 6.71 & 11.70 & $\begin{array}{c}\text { Pre- } \\
\text { soaked }\end{array}$ & 23.96 & 25.63 & 21.69 & 14.47 & 10.31 & 19.21 \\
\hline SIW & 14.81 & 14.72 & 14.72 & 8.13 & 2.79 & 11.03 & SIW & 24.83 & 22.67 & 20.66 & 12.16 & 4.39 & 16.94 \\
\hline $\begin{array}{c}\text { Mean } \\
\text { C }\end{array}$ & 13.68 & 15.52 & 14.42 & 8.46 & 4.75 & & $\begin{array}{c}\text { Mean } \\
\text { C }\end{array}$ & 24.39 & 24.15 & 21.17 & 13.31 & 7.35 & \\
\hline
\end{tabular}


Fig.1 LD ${ }_{50}$ curve for Ranchi Local in SIW condition

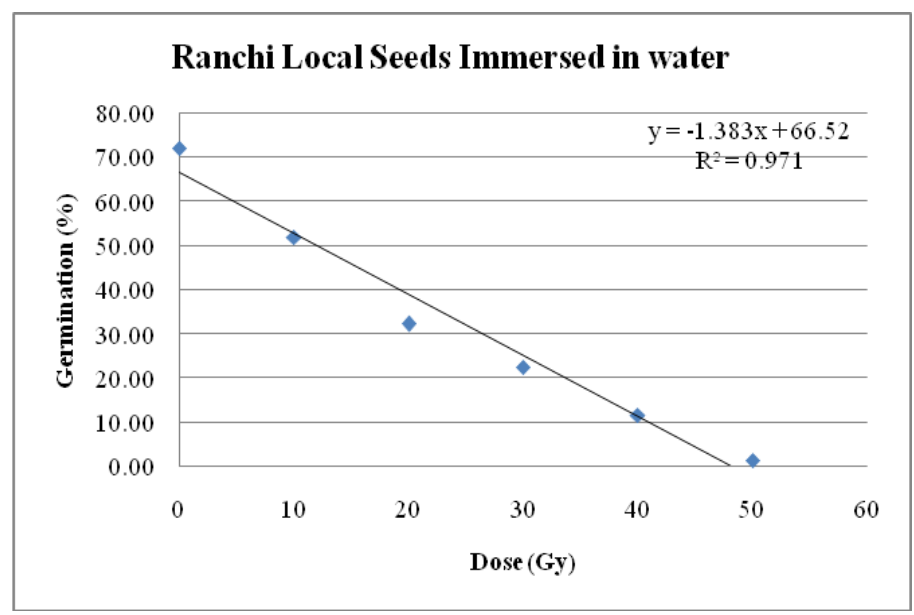

Fig.3 LD L0 $_{0}$ curve for Arka Surya in pre-soaked

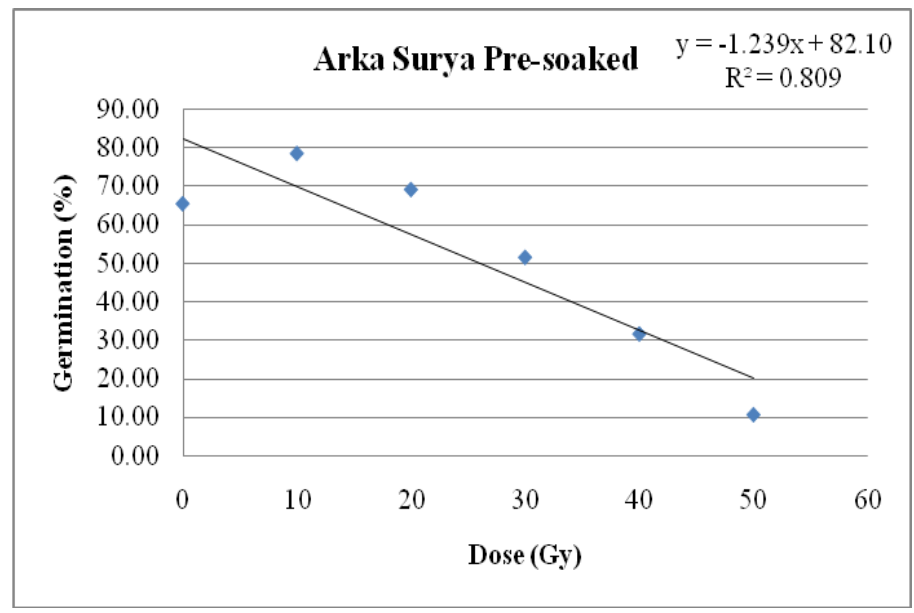

Fig.2 $\mathrm{LD}_{50}$ curve for Ranchi Local in presoaked seed condition

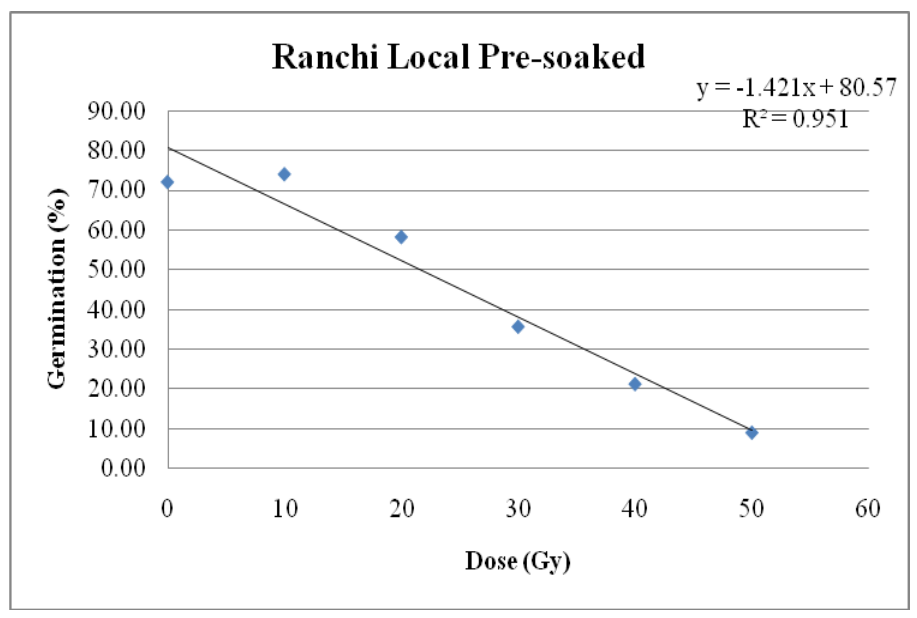

Fig.4 $\mathrm{LD}_{50}$ curve for Arka Surya in SIW condition

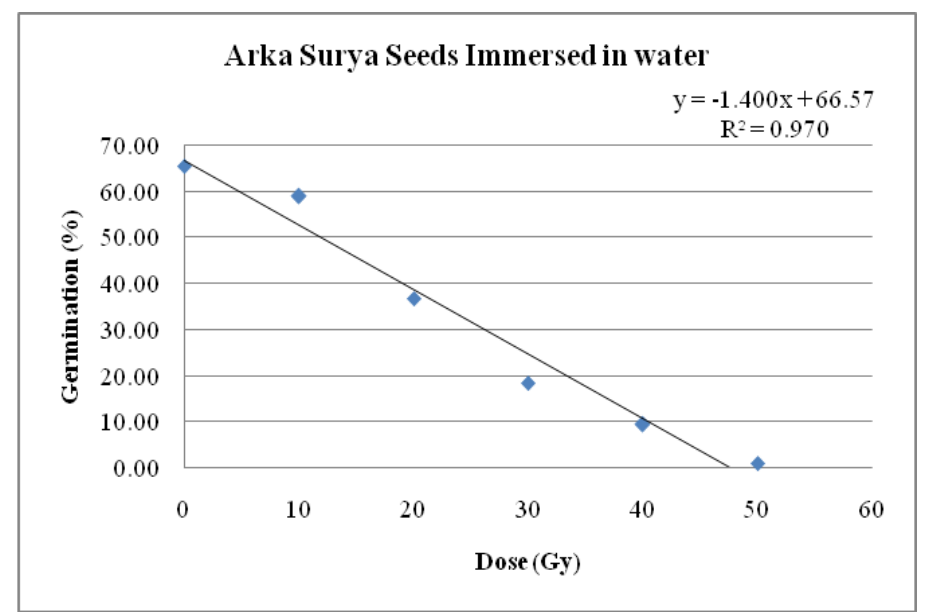

Fig.5 Effect of irradiation \& soaking on root length in papaya cv. Ranchi Local

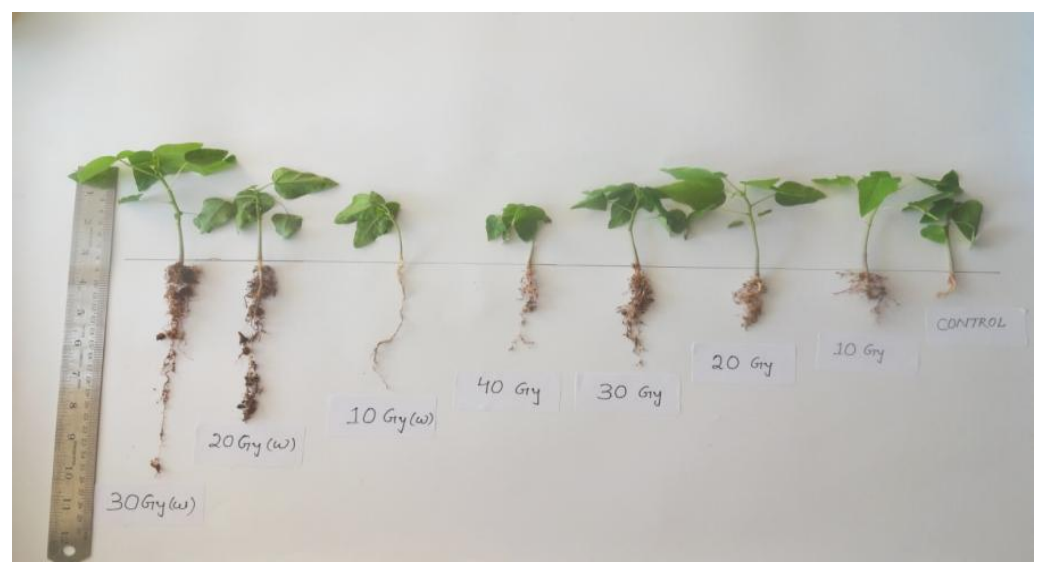


Fig.6 Growth rate curve for Ranchi Local in pre-soaked seed condition

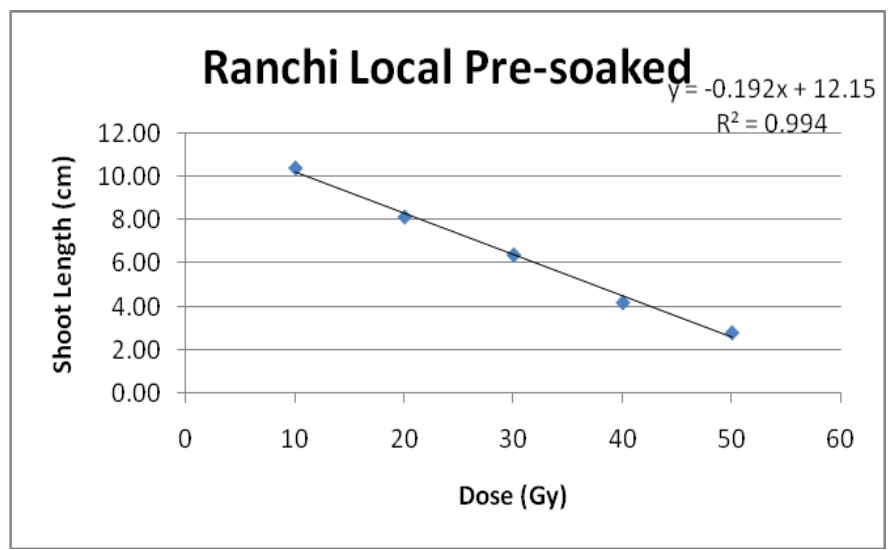

Fig.8 Growth rate curve for Arka Surya in pre-soaked seed condition

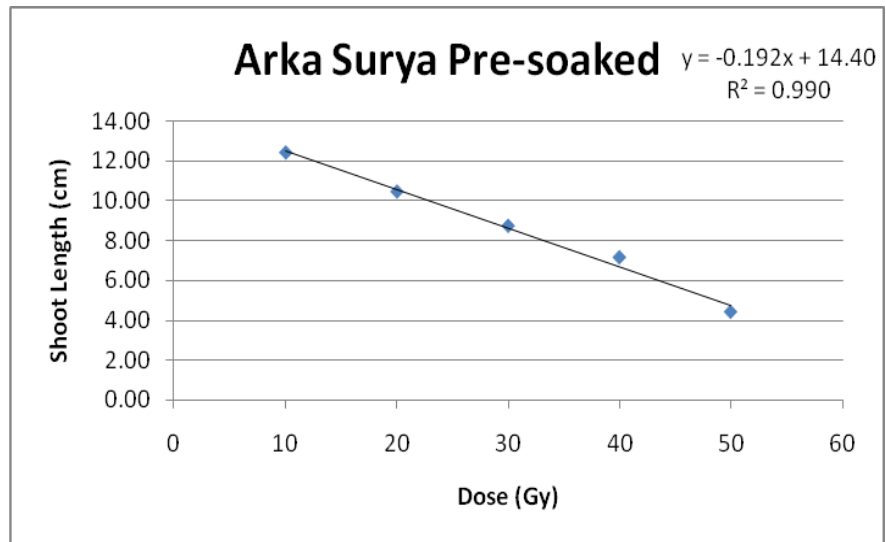

The symptoms frequently observed in the lowor high-dose-irradiated plants are enhancement or inhibition of germination, seedling growth, and other biological responses (Kim et al., 2000; Wi et al., 2007). Although, no certain explanations for the stimulatory effects of low-dose gamma radiation are available until now, in accordance to the results obtained by Wi et al., (2007), there is a hypothesis that the low dose irradiation will induce the growth stimulation by changing the hormonal signaling network in plant cells or by increasing the anti oxidative capacity of the cells to easily overcome daily stress factors such as
Fig.7 Growth rate curve for Ranchi Local in SIW seed condition

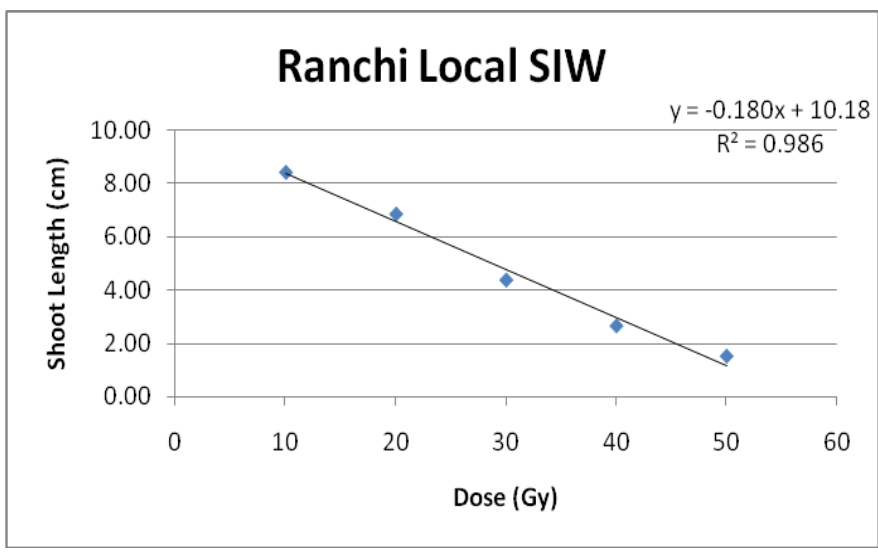

Fig.9 Growth rate curve for Arka Surya in SIW seed condition

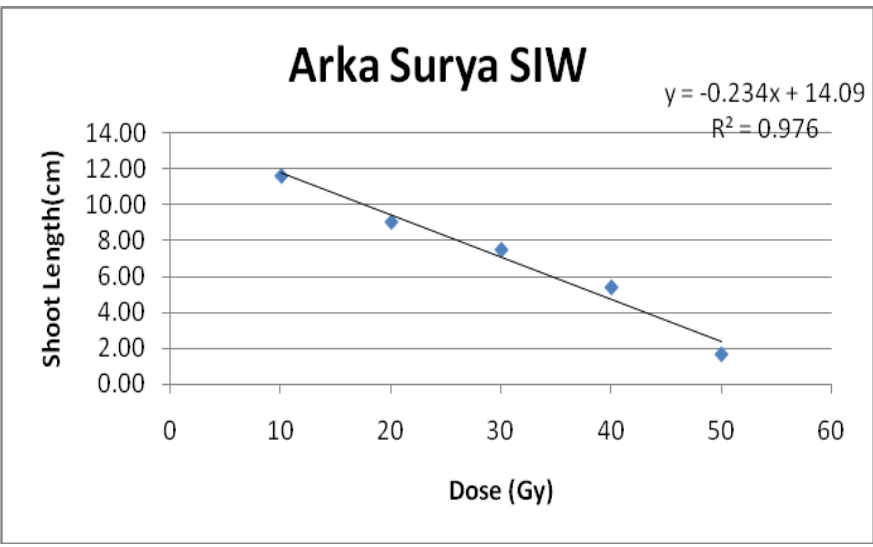

fluctuations of light intensity and temperature in the growth condition (Wi et al., 2007).

In contrast, the high-dose irradiation that caused growth inhibition has been ascribed to the cell cycle arrest at $\mathrm{G}_{2} / \mathrm{M}$ phase during somatic cell division and/or various damages in the entire genome (Preussa and Britta, 2003).

Low doses apparently inhibit auxin synthesis while larger doses can destroy auxin activity directly. As with higher wound responses, irradiated tissues often produce endogenous ethylene (Maxie et al., 1966; Dwelle, 1975; 
Chervin et al., 1992; Liu et al., 2008). Growth inhibition by gamma irradiation may be related to auxin and DNA biogenesis in a relationship as shown indicated in Figure 1.

These relationships postulate exclusive possibilities: (1) that DNA is required for and is previously synthesized sequentially to auxin formation, the radiation block occurring in the formation of nucleic acid; (2) that the primary radiation block is in auxin synthesis, the auxin required for the formation of DNA; and (3) that the effect of radiation is on an undefined entity in reaction previous to and essential for both DNA and auxin synthesis (Lage and Esquibel 1995; Momiyama et al., 1999). Radio sensitivity test of germinated seeds showed that $\mathrm{LD}_{50}$ was 28.35 and $33.13 \mathrm{~Gy}$ for pre-soaked seeds and 24.05 and 23.78 Gy for seeds immersed in water for Ranchi Local \& Arka Surya respectively. From the analysis of $\mathrm{GR}_{50}$ for both the irradiated conditions, it was found that $30 \mathrm{~Gy}$ (for pre-soaked seeds) and 20 Gy (for seeds immersed in water) was the most effective dose with maximum possibility of desirable mutation.

With the increasing gamma dose there was a significant decrease in germination percentage and shoot length, irrespective of variety and seed soaking conditions in papaya whereas gamma rays enhance root development However, the effect was more pronounced when seeds immersed in water during irradiation than pre-soaked seeds prior to irradiation.

\section{References}

A. Z. Hegazi and N. Hamideldin, "The effect of gamma irradiation on enhancement of growth and seed yield of okra [Abelmoschus esculentus (L.) Monech] and associated molecular changes, Journal of Horticulture and Forestry, vol.2, no.3, pp. $038-051,2010$.
Bayonove, J., Burg, M., Mir, A., and Delpoux, M. 1984. Biological changes observed on rice and biological and genetic changes observed on Tobacco after space flight in the orbital station Salyut- 7 (Biobloc III experiment). Adv. In. Space Res. 4(10): 97-101. doi:10.1016/0273-1177(84)90230-8.

Beyene D, Thunya T, Shermarl W and Benya M. 2013. Induced Mutation by Colchicine Treatment of Somatic Embryos in 'Namwa' Banana (Musa Spp. ABB). International Transaction Journal of Engineering, Management, Applied Science \& Technology, 4(4) : $311-320$.

Bora, K.C. 1961. Relative biological efficiencies of ionizing radiation on the induction of cytogenetic effect in plants. In Proceedings of the Symposium on the effect of ionizing radiation on seed and their significance for crop improvement. pp. 345-357.

Chattopadhyay, T.K. (2012). Papaya In: A texts book on pomology. Kalyani Publishers, New Delhi-11002 page No. 107-129

Chervin, C., Triantaphylides, C., Libert, M.F., Siadous, R., and Boisseau, P. 1992. Reduction of wound-induced respiration and ethylene production in carrot root tissues by gamma irradiation. Post Bio Tech, 2(1): 7-17. doi:10.1016/0925-5214(92)90022-H.

Choudhury RK (1983). A note on the effect of gamma irradiation in wheat. Wheat Info Sci 57:21-23

Dallwitz, M. J. (1980). A general system for coding taxonomic information. Taxon 29: 41-46.

Dwelle, R.B. 1975. Abscission of Phaseolus and Impateins explants: Effects of ionizing radiations upon endogenous growth regulators and in de novo enzyme synthesis. Plant Physiol. 56(4): 
529-534. doi:10.1104/pp.56.4.529. PMID:16659338.

Green RE, Cornell SJ, Scharlemann JP, Balmford A (2005) Farming and the fate of wild nature. Science 307:550555

Jan, S., Parween, T. and Siddiqi, T.O. 2011. Mahmooduzzafar. Effect of gammaradiation on morphological, biochemical, and physiological aspects of plants and plant products. Environ. Reviews, 20: 17-39

Kim J-S, Lee E-K, Baek M-H, Kim D-H, Lee YB (2000) Influence of low dose y radiation on the physiology of germinative seed of vegetable crops. Kor J Environ Agr 19:58-61

Kovacs, E. and A. Keresztes, 2002. Effect of gamma and UV-B/C radiation on plant cells. Micron, 33:199-210.

Kovács, E., and Keresztes, A. 2002. Effect of gamma and UV-B/C radiation on plant cells. Micron, 33(2): 199-210. doi:10.1016/ S0968-4328(01)00012-9. PMID:11567888.

Kumagai, J., Katoh, H., Kumada, T., Tanaka, A., Tano, S., Miyazakit, T., 2000. Strong resistance of Arabidopsis thaliana and Raphanus sativus seeds for ionizing radiation as studing by ESR, ENDOR, ESE spectroscopy and germina- tion measurement: eff ect of long lived and spur-lived radicals. Radiat. Phys. Chem. 57, 75-83.

Kumari, R., and Singh, Y. 1996. Effect of gamma-rays and EMS on seed germination and plant survival of Pisum sativum L., and Lens culinaris Medic. Neo Botanica, 4(1): 25-29.

Kuzin, A.M., Vagabova, M.E., and PrinakMirolyubov, V.N. 1975. Molecular mechanisms of the stimulating effect of ionizing radiation on seed. Activation of RNA synthesis. Radiobiol. 15: 747-750. PMID: 1208800
Kuzin, A.M., Vagabova, M.E., and Revin, A.F. 1976. Molecular mechanisms of the stimulating action of ionizing radiation on seeds. 2. Activation of protein and high molecular RNA synthesis. Radiobiol. 16: 259-261. PMID:1013306

Lage, C.L.S., and Esquibel, M.A. 1995. Role of non enzymatic synthesis of indole3 -acetic acid in the Ipomoea batatas $\mathrm{L}$. Lam. (sweet potato) response to gamma radiation. Arquivos de Biologia e Tecnologia, 38(4): 11731180.

Liu, H., Wang, Y., Xu, J., Su, T., Liu, G., and Ren, D. 2008. Ethylene signaling is required for the acceleration of cell death induced by the activation of AtMEK5 in Arabidopsis. Cell Res. 18(3): $\quad 422-\quad 432$. doi:10.1038/cr.2008.29. PMID:18268539.

Lokesha, R., Vasudeva, R., Shashidhar, H.E., and Reddy, A.N.Y. 1992. Radiosensitivity of Bambusa arundinacea to gamma rays. J. Trop. For. Sci. 6(4): 444-450.

Luckey, T.D. 1980. Hormesis with ionizing radiation. CRC Press Inc, Boca Raton.

Maluszynski M, Szarejko I, Maluszynski J (2003) Mutation techniques. In: Thomas B, Murphy DJ, Murray BG (eds) Encyclopedia of applied plant sci- ences. Elsevier Academic Press, San Diego, pp 186-201

Maxie, E.C., Sommer, N.F., Muller, C.J., and Rae, H.L. 1966. Effect of gamma irradiation on the ripening of Bartlett Pears. Plant Physiol. 41(3): 437-442. doi:10.1104/pp.41.3.437. PMID:16656274.

Momiyama, M., Koshiba, T., Furukawa, K., Kamiya, Y., and Satô, M. 1999. Effects of $\gamma$-irradiation on elongation and indole-3-acetic acid level of maize (Zea mays) coleoptiles. Environ. Exp. 
Bot. $\quad 41(2)$ : 131-143. doi:10.1016/S0098-8472(99)00005-2.

Preussa, S.B., Britta, A.B., 2003. A DNAdamage-induced cell cycle checkpoing in Arabidopsis. Genetics 164, 323-334

Purseglove, J. W. (1974). Tropical crops. Dicotyledon, vol. 1 and 2 combined, The English language Book Society and Longman, London.

Radhadevi, D.S., and Nayar, N.K. 1996. Gamma rays induced fruit character variations in Nendran, a varieties of banana (Musa paradasiaca L.). Geobios, 23: 88-93.

Roychowdhury R, Tah J. 2013 Mutagenesis A potential approach for crop improvement - Crop Improvement Springer.

Schroeder M.R. (1958). An artificial stereophonic effect obtained from a single audio signal. Journal of the Audio Engineering Society.

Shu QY, Forster BP, Nakagawa H (2012) Principles and applications of plant mutation breeding. In: Shu QY, Forster BP, Nakagawa H (eds) Plant mutation breeding and biotechnology. CABI Publishing, Walling ford, pp 301-324

Shu QY, Forster BP, Nakagawa H (2012) Principles and applications of plant mutation breeding. In: Shu QY, Forster BP, Nakagawa H (eds) Plant mutation breeding and biotechnology. CABI Publishing, Walling ford, pp 301-324.
Sparrow, A.H. 1966. Plant growth stimulation by ionizing radiations. In Effects of low doses of ionizing radiations on crop plants. IAEA Tech. Rep. Ser. Volume 64, pp. 12-15.

Thapa, C.B. 1999. Effect of acute exposure of gamma rays on seed germination of Pinus kesiya Gord and P. wallichiana A.B. Jacks. Botanica Orientalis. J. Plan. Sci. 2: 120-121. doi:10.3126/on.v2i1. 318.

Verma, A.K., Prasad, K.V., Singh, S.K. and Kumar, S. 2012. In vitro isolation of red coloured mutant from chimeric ray florets of chrysanthemum induced by gamma-ray. Indian J. Horticulture, 69: 562-567.

Wi SG, Chung BY, Kim JS, Kim JH, Baek MH, Lee JW, Kim YS (2007) Effects of gamma irradiation on morphological changes and biological responses in plants. Micron 38:553-564.

Zimmermann, M.W., Gartenbach, K.E., Kranz, A.R., Baican, B., Schopper, E., Heilmann, C., and Reitz, G. 1996. Recent results of comparative radiobiological experiments with short and long term expositions of Arabidopsis seed embryos. Adv. Space Res. 18(12): 205-213. doi:10.1016/0273-1177(96)00041-5. PMID: 11538965.

\section{How to cite this article:}

Prativa Sahu, D. K. Dash, J. Lenka, S. N. Dash, S. K. Tripathy, A. Mishra and Sahu, A. 2019. Standardisation of Gamma Dose in Papaya cv. Ranchi Local and Arka Surya. Int.J.Curr.Microbiol.App.Sci. 8(10): 361-373. doi: https://doi.org/10.20546/ijcmas.2019.810.037 